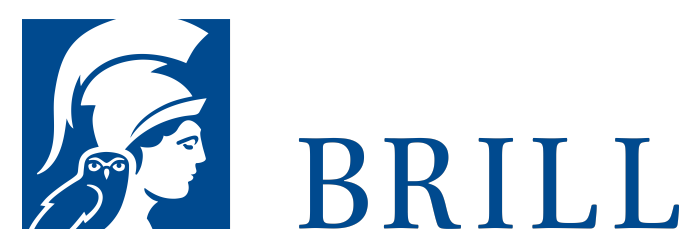

\title{
Die Giessener Zenonpapyri
}

\section{(P.Iand.Zen.)}

Author: Philip Schmitz

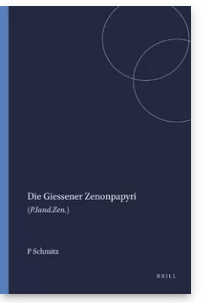

Pages: 277

Seiten

Language:

German

Subjects:

Ancient History, Classical Studies

Publisher: Brill |

Schöningh

Series:

Sonderreihe der Abhandlungen

Papyrologica Coloniensia,

Volume: 32

E-Book (PDF)

Released online:

18 Jan 2021

ISBN: 978-3-

657-76431-о

List price

USD $\$ 87.00$

Paperback

Publication date: 23 May 2007 ISBN: 978-3506-76431-7 
For more information see brill.com

Order information: Order online at brill.com +44330 333 0049 | customerservices@brill.com Submission information: brill.com/authors

Titles published by Brill | Fink, Brill | mentis or Brill | Schöningh: +49(o)715413279216| brill@brocom.de 